УДК 352/354.073.533(477)(045)

DOI https://doi.org/10.32838/TNU-2663-6468/2020.3/08

\title{
Таран E.I.
}

Національна академія державного управління при Президентові України

\section{ТРАНСФОРМАЦІЯ СИСТЕМИ ПУБЛІЧНОГО УПРАВЛІННЯ В УКРАЇНІ}

\begin{abstract}
У статті досліджено проиеси трансформаиії системи державного управління в публічне. Зокрема зазначено, щзо розвиток держсави та демократизація українського суспільства зумовили необхідність впровадження нових иінностей і процесів у діяльність органів влади, зокрема в систему державного управління. Обтрунтуванню иих змін мають передувати наукові дослідження зарубіжних та вітчизняних вчених, а також успішний досвід практичної реалізаиії змін системи державного управління у високорозвинутих краӥнах.

В умовах європейської інтеграції Украйни стає актуальною проблематика переходу від концепиії державного управління, де головним керівним суб'єктом суспільного розвитку $і$ регулювання суспільних відносин є держава, до системи публічного управління, яка уособлює ширший європейський конџепт з інституціями публічної влади до яких належать громадянське суспільство та приватні організаиії, щзо діють на рівноправних партнерських засадах із владними інституиіями.

Стаття розкриває підходи різних науковців до поняття державне управління, публічне адміністрування та публічне управління. Зокрема визначено, щзо еволюиія управління від державного до публічного пройшла шлях від жорсткого централізованого державного адміністрування до формування такого способу управління, який обмежує монополію держави та включає в себе характерні риси сучасного публічного управління - ефективність, прозорість, етику та справедливість вчинків. На відміну від державного, публічне управління забезпечує співпрачю держави, громадянського суспільства та бізнесу, які взаємодіють між собою з врахуванням потреб одне одного.

Також стаття розкриває відмінності між управлінням у приватній та публічній сферах. Так, у статті зазначено, що мета приватного управліния - отримання прибутку від підприємницької діяльності, в той час як робота публічного управліния спрямована на підвищення якості життя громадян.
\end{abstract}

Ключові слова: держсавне управління, публічне адміністрування, публічне управління, європейська інтеграчія, управління.

Постановка проблеми. Розвиток держави та демократизація українського суспільства зумовили необхідність впровадження нових цінностей і процесів у діяльність органів влади, зокрема в систему державного управління. Обгрунтуванню цих змін мають передувати наукові дослідження зарубіжних та вітчизняних вчених, а також успішний досвід практичної реалізації змін системи державного управління у високорозвинутих країнах.

За такої ситуації та в умовах євроінтеграційного курсу України дедалі більшої актуальності набуває проблематика переходу від концепції державного управління, 3 головним керівним суб'єктом суспільного розвитку та регулювання суспільних відносин - державою, до публічного управління, яке являє собою ширший європейський концепт і де регулювання процесами суспільного розвитку здійснюється системою інституцій публічної влади, до якої входять, зокрема, громадянське суспільство та приватні організації (бізнес), що діють на рівноправних партнерських засадах із владними інституціями.

Останнім часом тема публічного управління привертає увагу великої кількості науковців. Це відбувається у зв'язку з процесами децентралізації та європейської інтеграції, яка веде до переорієнтації у вітчизняній науці державного управління 3 розгляду окремо категорій державного управління, місцевого самоврядування і громадянського суспільства до їх системного бачення в контексті публічного управління.

Аналіз останніх досліджень і публікацій. Дослідивши наукові розвідки походження поняття «публічне управління», можемо зазначити, що воно було вперше використано англійським державним службовцем Д. Кіллінгом у 1972 p. Великий внесок у дослідження публічного управління було зроблено такими західними вче- 
ними: Г. Букертом, Б. Гурне, Г. Райтом, К. Полліттом та ін. Вітчизняні вчені також займаються проблемою розвитку публічного управління. Серед них можемо виділити Е. Афоніна, Л. Гонюкову, В. Козакова, В. Голуб, О. Оболенського, С. Телешуна, С. Чернова тощо. Водночас $€$ потреба дослідити причини і суть трансформації державного управління, яке 3 демократичними перетвореннями в суспільстві дедалі більше набуває ознак публічності, що і веде до становлення системи публічного управління.

Постановка завдання. Метою статті є дослідження та аналіз процесу трансформації системи державного управління в публічне управління.

Виклад основного матеріалу дослідження. Для кращого розуміння процесів, які відбуваються у системі державного управління та іiі трансформації в бік публічності, розглянемо саме поняття державного управління.

Класична концепція державного управління виокремлює такі його основні риси: управління державними справами, централізація управління, концентрація ресурсів, служіння загальнонаціональним інтересам [12], тобто в центрі державного управління знаходяться держава та її інтереси.

Дослідник В. Авер'янов під державним управлінням розуміє особливий вид діяльності держави, який грунтується на здійсненні нею управлінського, тобто організаційного впливу на сфери та галузі громадського життя, що вимагають певного втручання шляхом використання повноважень структур виконавчої влади [5].

О. Оболенський та А. Мельник під державним управлінням розуміють цілеспрямований організаційний та регулюючий вплив держави на стан та розвиток суспільних процесів, свідомість, поведінку та діяльність особи і громадянина 3 метою досягнення цілей та реалізації функцій держави, відображених в іiі законодавчих актах, шляхом запровадження державної політики, виробленої політичною системою та законодавчо закріпленою через діяльність органів державної влади $[11$, с. 32$]$.

Г. Атаманчук визначає державне управління як практичний, організуючий і регулюючий вплив держави (через систему своїх структур) на суспільну і приватну життєдіяльність людей із метою iii впорядкування, збереження або перетворення, що спирається на державну владну силу [1, с. 33].

Професор Т.О. Коломієць виокремлює вузьке і широке розуміння державного управління. Так, у вузькому розумінні державне управління - це сукупність державних органів, між якими певним чином розподілені різні види діяльності дер- жави. У широкому розумінні - це вид соціального управління та специфічної діяльності держави, що дістають вияв у функціонуванні іiі органів, які впливають на суспільні відносини з метою іiі урегулювання відповідно до державних інтересів [8].

У монографії «Суспільна трансформація і державне управління в Україні. Політико-правові детермінанти» державне управління визначено як соціальне явище, форми, методи, принципи i характер якого завжди зумовлюються потребами суспільного розвитку, що виявляються в інтересах певних соціальних верств і груп. На практиці це явище пов'язане із системою суспільних відносин не тільки через реальні управлінські процеси, що відбуваються у сфері суспільного виробництва, а й опосередковано через свідомість та певні форми знань. Характер, спрямованість і ступінь впливу на суспільні відносини тих чи інших управлінських чинників зумовлюються соціально-політичною природою суспільних сил, що стоять за ними [13].

В Енциклопедичному словнику 3 державного управління зазначено, що розуміння сутності державного управління зазнало еволюції внаслідок розвитку демократії та громадянського суспільства у світі та зокрема в Україні. Нині аспект взаємодії держави і громадянського суспільства в державному управлінні є дуже важливим, на відміну від традиційного бачення державного управління як організуючого й регулюючого впливу держави на суспільну життєдіяльність людей із метою ії упорядкування, зберігання або перетворення, що спирається на її владну силу [6].

Разом із тим в умовах ринкової економіки i 3 розвитком демократії, управління будь-якою організацією, незалежно від форм власності та напрямів діяльності, реалізовується, враховуючи демократичні суспільні зміни. Через це державне управління зі зміною суспільно-економічних відносин почало також зазнавати змін.

Серед громадян поширювалося невдоволення великою кількістю державних установ, але 3 низькою якістю надання ними послуг. Для покращення рівня обслуговування населення уряди багатьох країн світу наприкінці XX століття провели низку реформ. У цих кранах від державного управління почала відокремлюватися нова форма управління в публічному секторі - «публічне адміністрування». Воно визначається як цілеспрямована взаємодія публічних адміністрацій з юридичними i фізичними особами 3 приводу забезпечення реалізації законів й підзаконних актів та виконання частини основних функцій: орієнтуючого планування, що визначає бажані напрями розви- 
тку, створення правових, економічних та інших умов для реалізації інтересів учасників взаємодії, розподілу праці, кооперування і координування діяльності, моніторингу результатів [7, с. 77].

А. Колодій вважає, що публічне адміністрування $€$ різновидом управлінської діяльності інституцій публічної влади, за допомогою якої громадянське суспільство і держава забезпечують самоврядність (самокерованість) всієї системи суспільних відносин та їі розвиток [2].

Якщо у державному управлінні об'єктом виступає держава, то у публічному адмініструванні об'єктом є суспільство. До суб'єктів управління в державному управлінні належать органи виконавчої влади (уряд, міністерства, центральні органи виконавчої влади, місцеві державні адміністрації тощо), керівники і керівний склад усіх органів (політичні діячі, посадові особи, службові особи, які наділені державно-владними повноваженнями) [9].

У публічному адмініструванні суб'єктами виступають публічні адміністрації, які являють собою сукупність державних і недержавних структур та повноважних осіб, які здійснюють публічне урядування й адміністрування. До складу публічної адміністрації входять органи виконавчої влади, адміністративний апарат та виконавчі органи місцевого самоврядування [4, с. 21].

Низка науковців вважають, що публічне адміністрування $є$ перехідною ланкою, яка знаходиться на шляху трансформації державного управління в публічне управління.

Так, О. Босак зазначає, що в державному секторі модель публічного адміністрування («бюрократична модель») трансформувалася в модель публічного управління («ринкова модель») [3].

М. Міненко вважає, що в державному секторі акценти змінилися 3 виконання роботи згідно 3 інструкціями і чіткими правилами на роботу, яка полягає в наданні якісних публічних послуг i досягненні ефективних результатів. Це призвело до того, що відбулася трансформація державного управління в публічне адміністрування, яке згодом трансформувалося в публічне управління [10].

Так, вперше термін «публічне управління» був використаний англійським державним службовцем Д. Кіллінгом у 1972 р. На його думку, публічне управління - це пошук найкращого способу використання ресурсів задля досягнення пріоритетних цілей державної політики [15].

Г. Букерт, досліджуючи публічне управління, зазначає, що воно не є якимось нейтральним, технічним процесом, а натомість є діяльністю, яка тісно пов'язана 3 політикою, законом і громадянським суспільством [14, с. 26].

Становлення поняття «публічне управління» пов'язують із процесами передачі частини функцій держави органам місцевого самоврядування, приватного сектора та неурядовим організаціям. Тобто відбувається так званий процес «роздержавлення» управління.

Це призвело до того, що виконання управлінських функцій у публічній сфері (сфері суспільних інтересів) може здійснюватися не лише органами державної влади, а й органами місцевого самоврядування, громадськими організаціями і навіть фізичними і юридичними особами, якщо їх діяльність пов'язана з суспільними справами.

Управління від державного до публічного пройшло шлях від жорсткого централізованого державного адміністрування до формування такого способу управління, який обмежує монополію держави та розширює різноманітність методів управління. До характерних рис сучасного публічного управління належать ефективність, прозорість, етика та справедливість вчинків.

Необхідно визнати, що публічне управління взяло в основу приклади управління 3 приватного сектора, але порівняно з приватною сферою, управління в публічній сфері має свої особливості.

Основна відмінність між управлінням у приватній та публічній сфері - це те, що приватний управлінець має на меті отримання прибутку від певної підприємницької діяльності, а публічний управлінець своєю діяльністю прямо впливає на якість життя громадян, які мешкають на певній адміністративно-територіальній одиниці чи в державі загалом.

Висновки. Українське громадянське суспільство теж потребує нового підходу до управління, яке б змогло забезпечити ефективне задоволення суспільних потреб. Нині найефективнішою формою такого управління $\epsilon$ публічне управління. Публічне адміністрування виступає зв'язком між державним управлінням і публічним управлінням, а також реалізовує його рішення. Якщо основними елементами для державного управління $\epsilon$ держава та державна влада, то такими елементами для публічного управління виступають суспільство і публічна влада. На відміну від державного, публічне управління забезпечує співпрацю держави, громадянського суспільства та бізнесу, які взаємодіють між собою з врахуванням потреб одне одного. Для державного управління характерний авторитаризм, а публічне управління реалізується через демократію. 
Якщо державне управління реалізовує владні повноваження на основі закону, то публічне управління додатково зосереджується на ефективності з метою максимального задоволення потреб населення на основі мінімальних витрат.

Список літератури:

1. Атаманчук Г.В. Теория государственного управления: курс лекций, 4-е изд., дополн Москва : Омега-Л, 2006. $584 \mathrm{c}$.

2. Базарна О.В. Поняття, суть, природа публічного управління та державного управління. Вісник Східноукраӥнського наиіонального університету імені Володимира Даля: Збірник наукових праць. Луганськ : 2012. № 1, ч. 2. С. 60.

3. Босак О.3. Публічне управління як нова модель управління у державному секторі. Державне управління: теорія та практика : Збірник наукових праць. 2010. № 2.

4. Демократичне урядування та публічне адміністрування: проблеми вимірювання та аудиту : наук.метод. посібник / авт. кол.: А.Ф. Колодій, М.З. Буник, П.М. Петровський та ін. Київ : НАДУ, 2011. 56 с.

5. Державне управління в Україні : навч. посібник / За заг. ред. В.Б. Авер'янова. Киї : Ін-т держави і права ім. В.М. Корецького, 1999. 272 с.

6. Енциклопедичний словник з державного управління [Текст] / уклад. : Ю.П. Сурмін, В.Д. Бакуменко, А.М. Михненко та ін.; за ред. Ю.В. Ковбасюка, В.П. Трощинського, Ю.П. Сурміна. Київ : НАДУ, 2010.820 с.

7. Європеїзація публічного адміністрування в Україні в контексті європейської інтеграції : матеріали наук.-практ. конф. 17 груд. 2009 р., м. Дніпропетровськ / за заг. ред. Л.Л. Прокопенка. Дніпропетровськ : ДРІДУ НАДУ, 2009. 224 с. С. 77-78.

8. Коломоєць Т.О. Адміністративне право України. Академічний курс : підручник. Київ : Юрінком Iнтер, 2011. 576 c. URL: http://uadocs.exdat.com/docs/index-283028.html?page=9.

9. Малиновський В.Я. Державне управління : Навчальний посібник. Вид. 2-ге, доп. та перероб. Київ : Атіка, 2003. $576 \mathrm{c.}$

10. Міненко М.А. Трансформація системи державного управління в сучасні моделі регулювання суспільства. Державне управління: удосконалення та розвиток. Електронне фахове видання. URL: http://www.dy.nayka.com.ua/?op=1\&z=581.

11. Оболенський О.Ю. Державне управління : навч. посібник / А.Ф. Мельник, О.Ю. Оболенський, А.Ю. Васіна, Л. Ю. Гордієнко / за ред. А.Ф. Мельник. Київ : Знання-Прес, 2003. 343 с.

12. Пилипишин В.П. Щодо сутності мети та завдань державного управління в Україні. Форум права. 2010. № 2. C. 377-381. URL: http://www.nbuv.gov.ua/ejournals/FP/2010-2/10pvpuvu.pdf.

13. Цвєтков В.В. Суспільна трансформація і державне управління в Україні. Політико-правові детермінанти : монографія / Цвєтков В.В., Кресіна І.О., Коваленко А.А. Київ : «Ін Юре», 2003. 496 с. URL: http://archive.nbuv.gov.ua/portal/soc_gum/vsunu/2012_1_2/ Bazarna.pdf.

14. Bouckaert G. Modernizing the Rechtsstaat: Paradoxes of the Management Agenda. Berlin : Duncker \& Humblot, 2002.

15. Keeling D. Management in Government [Text]. London : Allen \& Unwin, 1972

\section{Taran Ye.I. TRANSFORMING THE PUBLIC MANAGEMENT SYSTEM IN UKRAINE}

The article examines the processes of transforming governance system into public management. It is particularly mentioned that development the state and the democratization of Ukrainian society necessitated introducing new values and processes in the activities of government, particularly in the system of governance. Substantiating these changes should be preceded by scientific research of foreign and domestic researchers, as well as successful experience in practically implementing changes in the system of governance in highly developed countries.

In the context of European integration of Ukraine, the issue of transition from the concept of governance, where the main leading subject of social development and regulation of public relations is the state, to the system of public management, which embodies a broader European concept with public authorities, including civil society and private organizations operating on the basis of equal partnership with government institutions is becoming topical.

The article reveals the approaches of various scholars to the concept of governance, public administration and public management. In particular, it is determined that evolution of government from governance to public management has gone from a rigid centralized governance to forming the mode of government that limits the state monopoly and includes the characteristics of modern public management - efficiency, transparency, ethics and fairness. Unlike governance, public management ensures the cooperation of the state, civil society and business, which interact with each other, taking into account each other's needs.

Besides, the article reveals the differences between management in the private and public areas. Thus, the article states that the purpose of a private manager is making a profit on entrepreneurial activity, while the work of a public manager is aimed at improving the quality of citizens'life.

Key words: governance, public management, public administration, European integration, management. 